\title{
Дослідження технології приготування робочих тіл парокомпресійних холодильних систем 3 добавками наночастинок $\mathrm{TiO}_{2}$
}

\author{
О. Я. Хлієва, Т. В. Лук'янова, Ю. В. Семенюк, В. П. Желєзний, С. Г. Корнієвич, О. Ю. Мельник \\ Одеська національна академія харчових технологій, вул. Канатна 112, м. Одеса, 65039, Україна
}

\begin{abstract}
У роботі розглянуто підходи до приготування робочих тіл парокомпресійних холодильних систем з добавками наночастинок оксидів металів - нанохолодоагентів. Показано, щуо до сих пір не розроблено технологї приготування агрегативно стабільних нанохолодоагентів. Як об'єкт дослідження для апробації різних технологій приготування нанохолодоагенту було обрано холодоагент R141b, як добавка - наночастинки TiO 2 двох виробників $i$ різні за своєю природою поверхнево-активні речовини (ПАР). Критерієм, щзо визначає якість отриманих нанофлюїдів, був середній розмір наночастинок у рідині, який визначався методом спектротурбідіметрії. Наведено результати експериментального дослідження впливу способу і тривалості диспергування наночастинок, а також добавок різних ПАР на розмір наночастинок в отриманих нанохолодоагентах. Наводяться рекомендаиії шуодо підвищення колоїдної стабільності диспергованих наночастинок $і$ зниження їхнього розміру в нанохолодоагентах, перспективних для застосування в холодильних системах.
\end{abstract}

Ключові слова: Холодоагент; Нанофлюїд; Поверхнево-активна речовина; Колоїдна стабільність; Розмір наночастинок у нанофлюїд $i$

(C) The Author(s) 2018. This article is an open access publication

This work is licensed under the Creative Commons Attribution 4.0 International License (CC BY) http://creativecommons.org/licenses/by/4.0/

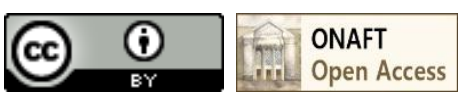

\section{1 Вступ}

Останні роки спостерігається підвищений інтерес до використання добавок наночастинок у робочих тілах парокомпресійних холодильних систем [1-3]. Наявні на сьогодні дослідження $[1,2,4,5]$ показують доцільність уведення наночастинок до складу робочих тіл з метою підвищення енергетичної ефективності холодильного обладнання. Як добавки в робочі тіла холодильного обладнання дослідники обирають переважно наночастинки оксидів металів, а також фулерени [1-3].

Розробка технології приготування й оцінка колоїдної стабільності робочих тіл $з$ добавками наночастинок мають передувати будь-яким дослідженням перспектив застосування нанофлюїдів ув реальних холодильних системах. Причому, на думку авторів, колоїдну стабільність (незмінність дисперсного складу з часом) нанофлюїду необхідно оцінювати не тільки в умовах їх зберігання, але і в процесі проведення експериментів 3 вимірювання теплофізичних властивостей, дослідження процесів теплообміну й енергетичної ефективності холодильної компресорної системи.

Слід зазначити, що в більшості робіт, присвячених експериментальним дослідженням теплофізичних властивостей або процесів 3 використанням нанохолодоагентів не приділяють належної уваги технології їх приготування. В результаті, навіть одні й ті ж дослідники не завжди отримують відтворювані результати як з теплофізичних властивостей нанофлюїдів, так і $з$ показників ефективності устаткування при їх використанні.

Оглядових робіт, присвячених розгляду технології приготування нанофлюїдів, досить багато [6-12]. Однак робіт, в яких розглядається методика приготування робочого тіла парокомпресійної холодильної машини 3 добавками наночастинок, всього декілька [3, 13, 25].

Метою даної роботи була оцінка впливу різних технологічних факторів процесу приготування нанохолодоагентів на основі холодоагенту R141b 3 добавками наночастинок $\mathrm{TiO}_{2}$ на колоїдну стабільність і середній розмір наночастинок в отриманих нанофлюїдах.

\section{1 Огляд існуючих технологій приготування нанофлюїдів}

В даний час виділяють два основні методи приготування нанофлюїдів: одноступінчатий і двоступінчатий.

Одноступінчатий метод полягає у формуванні наночастинок безпосередньо в рідині. При цьому можливий хімічний синтез наночастинок у рідині або формування наночастинок шляхом випаровування макроскопічних кількостей речовини 3 подальшою конденсацією в базовій рідині. Таку методику неможливо використовувати для легкокиплячих базових рідин, до яких належать холодоагенти $[5,14]$. У всіх наявних на сьогодні дослідженнях для приготування робочих тіл парокомпресійних холодильних систем 3 добавками наночастинок використовується двоступінчатий метод, заснований на диспергуванні сухих наночастинок у базовій рідині. Недоліком цього методу є складність якісного диспергування наночастинок у рідині. Хоча відзначається [5, 14], що ступінь дисперсності, а, отже, й інтенсифікація процесів тепловіддачі за рахунок присутності наночастинок у базовій рідині буде нижчим для нанофлюїдів, приготованих двоступінчатим методом, у порівнянні 3 нанофлюїдами, приготованими за одноступінчатим 
методом (при рівних концентраціях наночастинок у рідині).

Для диспергування сухих наночастинок у базовій рідині широко використовують ультразвукову обробку. Перевага цієї методики у порівнянні з механічним подрібненням 3 використанням молольних елементів обумовлена підвищеною чистотою одержуваних нанофлюїдів і високою якістю диспергування наночастинок. Недоліками $є$ нагрів рідини у процесі диспергування і високі енергетичні витрати на приготування нанофлюїдів. Альтернативою ультразвуковому диспергуванню при приготуванні нанофлюїдів є механічне подрібнення, здійснюване в кульових (бісерних), вібраційних, планетарних млинах. Недоліками механічного диспергування є тривалість процесу і можливе забруднення нанофлюїдів домішками від молольних елементів.

Разом $з$ тим, як показав попередній аналіз, використання виключно ультразвукової обробки для приготування нанофлюїдів не завжди є доцільним. Так, в роботі [14] стверджується, що при короткочасній ультразвуковій обробці суспензій не вдається досягти потрібного ступеня подрібнення частинок, а при занадто тривалій обробці виникає агрегація тонкодисперсних частинок. У роботі [15] показано, що при тривалій ультразвуковій обробці нанофлюїдів на основі етиленгліколю і ZnO роздроблені наночастинки знову починають збиратися в кластери. У роботі [16] показано, що значення дзетапотенціалу для нанофлюїдів на основі води і $\mathrm{Al}_{2} \mathrm{O}_{3}$ після ультразвукової обробки протягом 5 годин різко зросло. Однак при подальшій ультразвуковій обробці поступово почало знижуватися (що говорить про зниження колоїдної стабільності нанофлюїду). Авторами статті [16] було зроблено висновок про необхідність визначення оптимальної тривалості ультразвукової обробки нанофлюїдів у процесі їх приготування.

У періодичних наукових виданнях до сих пір відсутні публікації, в яких давалися б достатньо чіткі рекомендації щодо тривалості процесу диспергування наночастинок у базовій рідині. Однак у низці робіт відзначається необхідність контролю розміру наночастинок у процесі приготування нанофлюїдів [14, 17], дзетапотенціалу [16], теплопровідності $[18,19]$ або в'язкості [18]. Відомо, що розмір наночастинок у рідині визначає такі властивості нанофлюїдів як теплопровідність і в'язкість. Саме ці властивості нанофлюїдів визначають перспективність їх застосування як робочих тіл парокомпресійних холодильних систем.

Деякі дослідники пропонують використовувати поєднання ультразвукового і механічного диспергування наночастинок $[17,20]$. За такого підходу при механічному дробленні в агрегатах наночастинок утворюються тріщини, через які при подальшій ультразвуковій обробці агрегати руйнуються у результаті кавітаційних явищ у рідині. Результати проведеного попереднього дослідження підтверджують доцільність застосування методики, яка складається з комбінації ультразвукового i механічного впливу (з попереднім ультразвуковим диспергуванням). Доцільність комбінованого підходу до диспергування нанофлюїдів буде сприяти зниженню енерговитрат на приготування нанофлюїдів, оскільки ультразвукова обробка характеризується великою витратою енергії у порівнянні з механічною.

\section{2 Об'єкти дослідження}

У представленому дослідженні як базова рідина для приготування нанофлюїдів було обрано холодоагент R141b, CAS № 1717-00-6 (виробник Zhejiang mr refrigerant co. Ltd, Китай). Як добавки використовувалися наночастинки $\mathrm{TiO}_{2} \mathrm{CAS}$ № 1317-70-0 з розміром у порошку менш 25 нм (Sigma-Aldrich) і з середнім розміром 18 нм (Wenzhou Jingcheng Chemical Co).

Вибір матеріалу наночастинок $\left(\mathrm{TiO}_{2}\right)$ обумовлюється їхніми хімічною стабільністю, відпрацьованою технологією виробництва і низькою вартістю. Холодоагент $\mathrm{R} 141 \mathrm{~b}$ було обрано як базову речовину з кількох причин. По-перше, цей холодоагент знаходиться в рідкому стані при температурі навколишнього середовища i атмосферному тиску, тому його зручно використовувати при приготуванні нанофлюїду. По-друге, незважаючи на відмінності у фізичних властивостях R141b i тих холодоагентів, що знайшли в даний час широке застосування (R134a, R410A й інші), всі вони належать до однієї групи галоїдопохідних вуглеводнів. Тому закономірності, отримані при дослідженні технології приготування модельної системи R141b/наночастинки, можуть бути поширені й на інші галоїдопохідні холодоагенти, які широко використовуються в холодильній промисловості.

Для забезпечення колоїдної стабільності нанофлюїдів проводився підбір різних за своєю природою поверхнево-активних речовин (ПАР): аніонні ПАР SDBS (Sodium dodecylbenzenesulfonate, CAS № 25155-30-0) i SDS (Sodium dodecyl sulfate, CAS № 151-21-3); катіонна ПАР СТАВ (Cetyl trimethilammonium bromide, CAS № 57-09-0); неіоногенна ПАР Span 80 (Sorbitane monooleate, CAS № 1338-43-8). Усі ПАР виробництва Sigma-Aldrich.

Об'єктами дослідження були такі нанохолодоагенти: - холодоагент $\mathrm{R} 141 \mathrm{~b} /$ наночастинки $\mathrm{TiO}_{2}$ (Wenzhou Jingcheng Chemical Co) (99,912/0,088\% мас.) без ПАР і 3 різним вмістом ПАР;

- холодоагент R141b/наночастинки $\mathrm{TiO}_{2}$ (Sigma Aldrich) (99,90/0,10\% мас.) без ПАР і з різним вмістом ПАР.

\section{3 Методи та обладнання експериментального дослідження}

Для визначення масових концентрацій наночастинок у зразках нанофлюїдів застосовувався гравіметричний метод з використанням аналітичних ваг AND GR300 з невизначеністю $\pm 0,5$ мг.

Для ультразвукової обробки нанофлюїду використовувалася ультразвукова ванна Codison CD 4800, частота 42 кГц, потужність 0,07 кВт.

Для механічного диспергування нанофлюїду використовувався бісерний млин, заповнений кульками 3 $\mathrm{ZrO}_{2}$ діаметром 2 мм.

Для визначення середнього розміру наночастинок у нанофлюїді застосовувався метод спектротурбідіметрії [21-23]. Середній розмір наночастинок було прийнято 
як параметр для контролю якості приготованих нанофлюїдів. Слід зазначити, що «істинний» розмір наночастинок можна визначити лише методом електронної мікроскопії, який не можна застосувати для дослідження наночастинок у рідинах. Наразі для оцінки розміру наночастинок у рідині найбільшого поширення на практиці отримав метод динамічного розсіювання світла (метод фотонної кореляційної спектроскопії). Але певні перспективи $є$ у простішого з позиції апаратного оформлення методу, заснованого на явищі статичного розсіювання світла на неоднорідностях в рідині - методу спектротурбідіметріі.

Необхідною умовою використання методу спектротурбідіметріі для оцінки розміру наночастинок $є$ відсутність поглинання світла наночастинками, а також відсутність вторинного світлорозсіювання (що дотримується при малих концентраціях дисперсної фази). Для багатьох перспективних для застосування в холодильних системах нанофлюїдів (на основі таких рідин як галоїдопохідні холодоагенти та компресорні мастила 3 добавками наночастинок оксидів металів, наприклад, $\mathrm{TiO}_{2}, \mathrm{Al}_{2} \mathrm{O}_{3}$ ) необхідні умови дотримуються.

Практична реалізація методу спектротурбідіметрії при дослідженні розміру наночастинок у нанофлюїдах полягала у вимірюванні спектральної залежності коефіцієнта пропускання падного світла $T$ зразками нанофлюїдів відносно коефіцієнта пропускання зразком базової рідини. Вимірювання проводилися спектрофотометром Shimadzu UV-120-02 у плоскопаралельних оптичних комірках з довжиною оптичного шляху 1,05 мм при декількох значеннях довжини хвилі $\lambda$ видимої частини спектру.

\section{4 Технологія приготування нанохолодоаген- тів}

Для приготування усіх зразків нанофлюїдів використовувався двоступеневий метод, який складався 3 таких етапів:

- ультразвукова обробка суміші наночастинок і холодоагенту в присутності ПАР або без додавання ПАР протягом 30 хвилин;

- механічне диспергування протягом 12 годин;
- ультразвукова обробка протягом 30 хвилин.

Приготувати колоїдно стабільний нанофлюїд $\mathrm{R} 141 \mathrm{~b} /$ наночастинки $\mathrm{TiO}_{2}$ без використання ПАР не вдалося (див. рис. 1). Причому про агрегативну нестійкість отриманого флюїду говорить той факт, що рідина над осадом практично не містить наночастинок. Цей результат суперечить інформації, наведеній у роботі [24], де відзначається задовільна колоїдна стабільність (протягом 3-4 тижнів) системи R141b/наночастинки $\mathrm{TiO}_{2}$ (0,01 - 0,05 об. \%, середній розмір у порошку 21 нм), приготованої за допомогою ультразвукового диспергування протягом 6 годин без добавок ПАР.

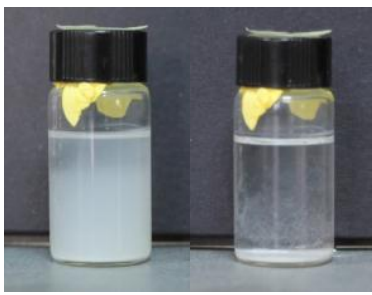

$a$ $\sigma$

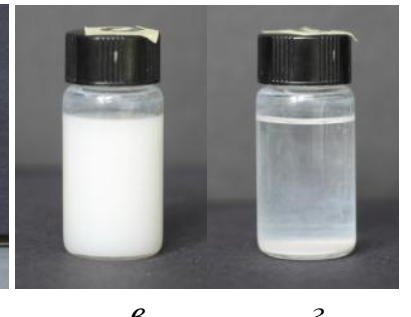

6 2
Рисунок 1 - Зразки нанофлюїдів R141b/наночастинки $\mathrm{TiO}_{2}$ : $a$ i $\sigma$ - наночастинки $\mathrm{TiO}_{2}$ виробництва Sigma Aldrich (0,088 мас.\%): фотографії зроблені через 1 годину і через 18 годин після приготування, відповідно; в i 2 - наночастинки $\mathrm{TiO}_{2}$ виробництва Wenzhou Jingcheng Chemical Co (0,10 мас.\%): фотографії зроблені відразу і через 20 годин після приготування, відповідно

Для забезпечення колоїдної стабільності нанофлюїду було проведено додаткові дослідження з вибору типу і концентрації ПАР. Розглядалися різні за своєю природою ПАР: аніонні SDBS і SDS; катіонна СТАВ; неіоногенна Span 80. При приготуванні усіх зразків нанофлюїдів 3 добавками ПАР необхідна кількість ПАР додавалася перед останнім етапом приготування - ультразвуковою обробкою. Концентрації ПАР у зразках нанофлюїду $\mathrm{R} 141 \mathrm{~b} /$ наночастинки $\mathrm{TiO}_{2}$ наведено у таблиці 1.

Фотографії усіх зразків нанофлюїду з наночастинками $\mathrm{TiO}_{2}$ (Wenzhou Jingcheng Chemical Co) 0,088 мас. \%. через 20 годин після приготування наведено на рис. 2.

Таблиця 1 - Концентраціі ПАР у зразках нанофлюїду $\mathrm{R} 141 \mathrm{~b} /$ наночастинки $\mathrm{TiO}_{2}$

\begin{tabular}{|c|c|c|c|c|c|c|c|}
\hline $\begin{array}{c}\text { № } \\
\text { зразка }\end{array}$ & $\begin{array}{l}\text { ПАР / } \\
\text { мас.\% }\end{array}$ & $\begin{array}{c}\text { № } \\
\text { зразка }\end{array}$ & $\begin{array}{c}\text { ПАВ / } \\
\text { мacc. \% }\end{array}$ & $\begin{array}{c}\text { № } \\
\text { зразка }\end{array}$ & $\begin{array}{l}\text { ПАВ / } \\
\text { мaс. \% } \\
\end{array}$ & $\begin{array}{c}\text { № } \\
\text { зразка }\end{array}$ & $\begin{array}{l}\text { ПАВ / } \\
\text { мас. \% } \\
\end{array}$ \\
\hline \multicolumn{8}{|c|}{ наночастинки $\mathrm{TiO}_{2}$ (Wenzhou Jingcheng Chemical Co) } \\
\hline 0 & Відсутня & 5 & Span/0,016 & 10 & SDBS/0,015 & 14 & SDS/0,014 \\
\hline 1 & CTAB/0,016 & 6 & Span/0,038 & 11 & SDBS/0,045 & 15 & SDS/0,034 \\
\hline 2 & CTAB/0,042 & 7 & Span/0,058 & 12 & SDBS/0,092 & 16 & SDS/0,063 \\
\hline 3 & CTAB/0,080 & 8 & Span/0,082 & 13 & SDBS/0,108 & 17 & SDS/0,083 \\
\hline 4 & CTAB/0,086 & 9 & Span/0,118 & & & & \\
\hline \multicolumn{8}{|c|}{ наночастинки $\mathrm{TiO}_{2}$ (Sigma Aldrich) } \\
\hline 0 & Відсутня & 2 & CTAB/0,108 & 4 & Span/0,062 & & \\
\hline 1 & CTAB/0,052 & 3 & Span/0,035 & 5 & Span/0,103 & & \\
\hline
\end{tabular}




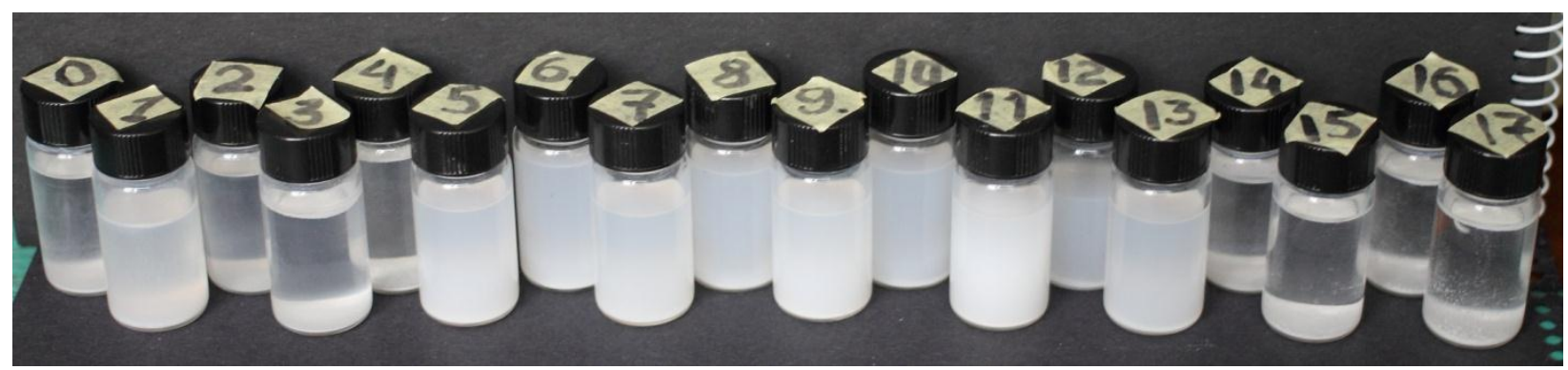

Рисунок 2 - Фотографії нанофлюїду R141b/наночастинки TiO2 (Wenzhou Jingcheng Chemical Co) $(0,088 / 99,912 \%$ мас.) (Номер на кришці відповідає номеру зразка в таблиці 1)

Для оцінки впливу добавок ПАР на ступінь дисперсності отриманих нанофлюїдів для зразків 3 наночастинками $\mathrm{TiO}_{2}$ (Wenzhou Jingcheng Chemical Co), які виявили достатню колоїдну стабільність, було проведено вимірювання середнього розміру наночастинок відразу після приготування і через 20 годин. Причому зразки, для яких спостерігалося осідання наночастинок відразу після приготування (усі зразки з ПАР СТАВ і SDS) для подальших досліджень не використовувалися. Крім того, для оцінки можливості підвищення ступеня дисперсності нанофлюїдів на основі R141b i наночастинок $\mathrm{TiO}_{2}$ (Wenzhou Jingcheng Chemical Co) стійкі зразки (з добавками ПАР Span 80 i SDBS) піддавалися додатковому ультразвуковому диспергуванню. На першому етапі ультразвукова обробка проводилася протягом 2,5 годин, на другому - протягом 2,0 годин. Після кожного етапу диспергування проводилося вимірювання розміру наночастинок у приготованих зразках.

Результати вимірювання розміру наночастинок на різних етапах дослідження зразків нанофлюїдів у залежності від концентрації ПАР наведено на рис. 3. Як випливає з наведеного рисунка, високого ступеня дисперсності (менше 100 нм) у досліджуваних зразках отримати не вдалося, навіть 3 використанням додаткової ультразвукової обробки. Хоча ультразвукова обробка, проведена у присутності ПАР, все ж сприяла зменшенню розміру наночастинок у рідині - рис. 3 .

Вибір оптимальної концентрації ПАР є дуже складним завданням. Слід враховувати, що надлишок ПАР може
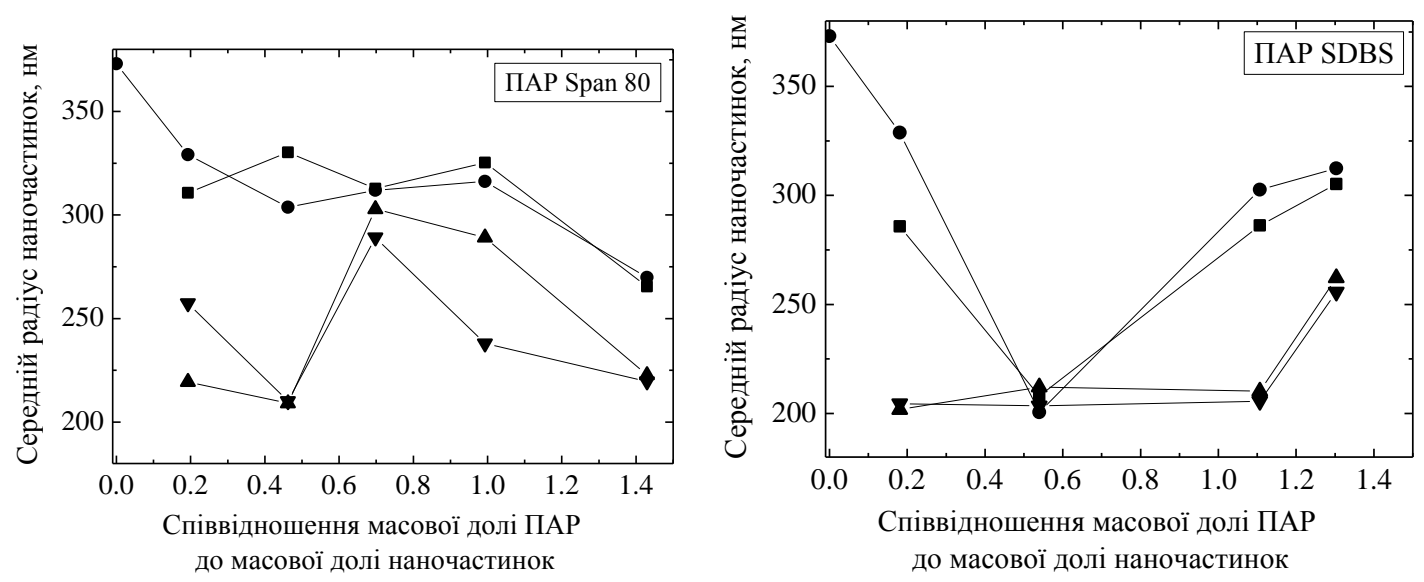

Рисунок 3 - Залежність середнього розміру наночастинок у нанофлюїдах в залежності від концентрації ПАР: a - ПАВ Span 80; б - ПАВ SDBS: • - відразу після приготування, - - через 20 годин зберігання, $\boldsymbol{\Delta}$ - через 20 годин зберігання та 2,5 години ультразвукової обробки; $\boldsymbol{\nabla}$ - через 20 годин зберігання та 4,5 години ультразвукової обробки 
Проведені дослідження показують, що через 20 годин зберігання приготованих нанофлюїдів у статичних умовах навіть у зразках $\mathrm{R} 141 \mathrm{~b} /$ наночастинки $\mathrm{TiO}_{2}$ (Wenzhou Jingcheng Chemical Co) 3 ПAP Span 80 i SDBS спостерігався невеликий щільний осад. При цьому зразки нанофлюїдів мали різну оптичну густину по висоті комірок. Додатково для цих зразків було виміряно середній розмір наночастинок через 20 годин їх зберігання (з попередніми збовтуванням зразків перед заправкою в оптичні комірки). Отримані дані показують, що середній розмір наночастинок у всіх зразках за увесь період зберігання практично не змінився. Слід зазначити, що середній розмір наночастинок у нанофлюїдах був досить великим (рис. 3). Це $\epsilon$ причиною часткового осідання великих частинок у комірках. Разом з тим слід зазначити, що у нанофлюїді, приготованому з використанням ПАР SDBS, при його подальшому зберіганні (протягом місяця) спостерігалося укрупнення й осідання наночастинок, чого не спостерігалося у нанофлюїді з ПАР Span 80.

За описаною вище технологією також було приготовано нанофлюїди 3 використанням наночастинок $\mathrm{TiO}_{2}$ виробництва Sigma Aldrich. Типи і концентрації використаних ПАР наведено у таблиці 1. Приготувати колоїдно стабільні зразки нанофлюїдів з використанням ПАР СТАВ не вдалося. Для зразків $\mathrm{R} 141 \mathrm{~b} /$ наночастинки $\mathrm{TiO}_{2}$ (Sigma Aldrich) 3 ПАР Span 80 незалежно від концентрації ПАР через 18 годин зберігання візуальні спостереження показали наявність градієнта оптичної густини нанофлюїдів по висоті комірок. Слід зазначити, що осаду наночастинок на дні оптичних комірок не спостерігалося. Розмір наночастинок $\mathrm{TiO}_{2}$ (Sigma Aldrich) у даних зразках нанофлюїдів відразу після приготування становив $131 \pm 3$ нм, що істотно нижче, ніж для нанофлюїдів 3 наночастинками $\mathrm{TiO}_{2}$ (Wenzhou Jingcheng Chemical Co) при дотриманні однакової технології приготування. Причому залежності отриманого розміру наночастинок від концентрації ПАР виявлено не було (в межах невизначеності вимірювання розміру наночастинок).

Пояснити відмінність розмірів наночастинок у нанофлюїдах при використанні наночастинок різних виробників (з приблизно однаковим початковим розміром у порошку) можна як невідповідністю заявленого виробником розміру наночастинок реальним розмірам, так і зміною заявленого виробником розміру наночастинок з часом у процесі їх зберігання.

Результати проведених досліджень (див. рис. 3) показують, що додаткове ультразвукове диспергування зразків нанофлюїдів з ПАР призводить до суттєвого зменшення розміру наночастинок. На підставі отриманих даних можна зробити висновок про те, що диспергування наночастинок $\mathrm{TiO}_{2}$ у холодоагенті R141b необхідно здійснювати у присутності ПАР, а не вводити ПАР на останньому етапі приготування нанофлюїдів. На думку авторів, ПАР виконує роль диспергувального агента при приготуванні нанофлюїдів. Так, при приго- туванні зразків нанофлюїдів 3 наночастинками $\mathrm{TiO}_{2}$ (Sigma Aldrich) 0,10 мас. \% і ПАР Span 80 0,10 мас. \% для досліджень процесів кипіння ПАР додавалося перед механічним диспергуванням наночастинок в бісерному млині, а не після, як в наведених раніше дослідженнях. У цьому випадку розмір наночастинок, виміряний методом спектротурбідіметрії відразу після приготування нанофлюїдів, склав (100...107) нм (результат багаторазових вимірювань), що менше отриманих раніше розмірів $131 \pm 3$ нм при однаковій тривалості всіх етапів диспергування.

\section{5 Колоїдна стабільність нанохолодоагенту при дослідженні процесу його кипіння}

Для дослідження колоїдної стабільності нанохолодоагенту при проведенні експериментального дослідження процесів його кипіння і при подальшому його зберіганні використовувався зразок нанофлюїду складу: холодоагент R141b 99,8\% мас. \%, наночастинки $\mathrm{TiO}_{2}$ (Sigma Aldrich) 0,10 мac. \% i ПАР Span 80 0,10 мас. $\%$.

Дослідження розміру наночастинок у приготованих зразках проводилися багаторазово протягом двох місяців. Ці вимірювання здійснювалися відразу після приготування нанофлюїду, в процесі проведення експерименту з дослідження тепловіддачі при кипінні (відбір зразків здійснювався безпосередньо 3 експериментальної установки), а також після закінчення експерименту при зберіганні нанофлюїду в герметичній ємності. Перед відбором нанофлюїдів з ємності зразок піддавався інтенсивному перемішуванню. Результати зміни розмірів наночастинок у нанофлюїді з часом наведено рис. 4.

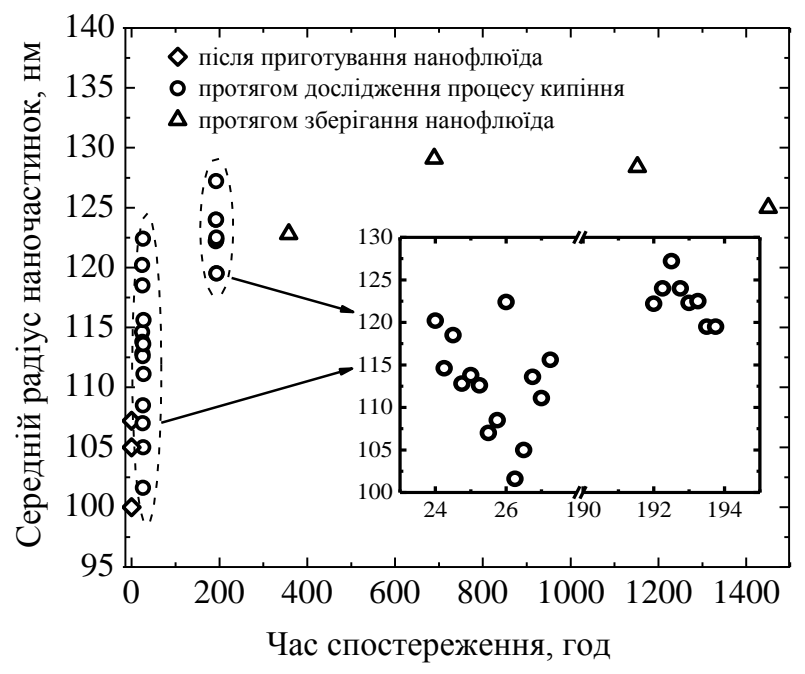

Рисунок 4 - Залежність середнього розміру наночастинок у нанофлюїді від часу

Результати проведених досліджень показують, що після приготування зразків нанофлюїдів протягом декількох днів розмір наночастинок збільшується з середнього розміру 104 нм до середнього розміру 125 нм. Подальшого збільшення розмірів наночастинок у досліджуваних нанофлюїдах з часом не спостерігалося. 
Розкид значень розмірів наночастинок при кипінні нанохолодоагенту, ймовірно, можна пояснити наявністю тимчасових кластерів, які утворювалися у зонах локальних підвищень концентрацій наночастинок, що виникали внаслідок тепломасообмінних процесів.

\section{Висновки}

У статті подано аналіз існуючих методів приготування нанофлюїдів, перспективних для застосування в якості робочих тіл парокомпресійних холодильних машин. На підставі проведених досліджень зроблено висновок про доцільність комбінування механічного та ультразвукового диспергування наночастинок у базових рідинах при приготуванні нанохолодоагентів двоступінчатим методом.

Обгрунтовано вибір поверхнево-активної речовини для приготування нанофлюїдів на основі галоїдопохідних холодоагентів - неіоногенної ПАР Span 80, яка забезпечує колоїдну стабільність нанофлюїду на основі холодоагенту R141b i наночастинок $\mathrm{TiO}_{2}$. Показано, що процедура визначення оптимальної концентрації ПАР для приготування нанофлюїдів є достатньо складною і залежить від багатьох факторів. Показано, що зі зменшенням розміру наночастинок у нанофлюїді (в результаті ультразвукової обробки) збільшується необхідна кількість ПАР для забезпечення колоїдної стабільності (через збільшення питомої поверхні наночастинок). Тому для кожного конкретного зразка нанофлюїду перед початком дослідження його теплофізичних властивостей або процесів теплообміну необхідно експериментально визначати оптимальну концентрацію ПАР.

На підставі отриманих результатів можна зробити висновок про необхідність подальших досліджень щодо розробки технологій приготування нанофлюїдів.

\section{Литература}

1. Celen A. et al. A review of nanorefrigerants: Flow characteristics and applications // International Journal of Refrigeration. 2014. Vol. 44. P. 125-140. doi: 10.1016/j.ijrefrig.2014.05.009.

2. Azmi W.H. et al. Potential of nanorefrigerant and nanolubricant on energy saving in refrigeration system - A review // Renewable and Sustainable Energy Reviews. 2017. Vol. 69. P. 415-428. doi: 10.1016/j.rser.2016.11.207. 3. Alawi O.A., Sidik N.A.C., Mohammed H.A. A comprehensive review of fundamentals, preparation and applications of nanorefrigerants // International Communications in Heat and Mass Transfer. 2014. Vol. 54. P. 81-95. doi: 10.1016/j.icheatmasstransfer.2014.03.001.

4. Lukianov $\mathbf{M}$ et al. Nanorefrigerants application possibilities study to increase the equipment ecologicalenergy efficiency // Eastern-European Journal of Enterprise Technologies. 2015. Vol. 3. No 5(75). P. 32. doi: 10.15587/1729-4061.2015.42565.

5. Мороз С.А. и др Экспериментальное исследование влияния примесей фуллеренов С60 в компрессорном масле и величины вязкости масла на показатели эффективности холодильной компрессорной системы // Вестник Международной академии холода. 2016. № 1. 4146 doi: 10.21047/1606-4313-2016-16-1-41-46.

6. Haddad $\mathbf{Z}$. et al. A review on how the researchers prepare their nanofluids // International Journal of Thermal Sciences. 2014. Vol. 76. P. 168-189. doi: 10.1016/j.ijthermalsci.2013.08.010.

7. Devendiran D.K., Amirtham V.A. A review on preparation, characterization, properties and applications of nanofluids // Renewable and Sustainable Energy Reviews. 2016. Vol. 60. P. 21-40. doi: 10.1016/j.rser.2016.01.055.

8. Ghadimi A., Saidur R., Metselaar H.S.C. A review of nanofluid stability properties and characterization in stationary conditions // International Journal of Heat and Mass Transfer. 2011. Vol. 54. No 17-18. P. 4051-4068. doi: 10.1016/J.IJHEATMASSTRANSFER.2011.04.014.

9. Wu D. et al. Critical Issues in Nanofluids Preparation, Characterization and Thermal Conductivity // Current Nanoscience. 2009. Vol. 5. No 1. P. 103-112. doi: 10.2174/157341309787314548.

10. Yu W., Xie H. A Review on Nanofluids: Preparation, Stability Mechanisms, and Applications // Journal of Nanomaterials. 2012. Vol. 2012. P. 1-17. doi: $10.1155 / 2012 / 435873$.

11. Diao Y.H. et al. Experimental investigation on the pool boiling characteristics and critical heat flux of $\mathrm{Cu}-\mathrm{R} 141 \mathrm{~b}$ nanorefrigerant under atmospheric pressure // International Journal of Heat and Mass Transfer. 2015. Vol. 89. P. 110115. doi: 10.1016/j.ijheatmasstransfer.2015.05.043.

12. Li Y. et al. A review on development of nanofluid preparation and characterization // Powder Technology. 2009. Vol. 196. No 2. P. 89-101. doi: 10.1016/J.POWTEC.2009.07.025.

13. Peng H., Lin L., Ding G. Influences of primary particle parameters and surfactant on aggregation behavior of nanoparticles in nanorefrigerant // Energy. 2015. Vol. 89. P. 410-420. doi: 10.1016/j.energy.2015.05.116.

14. Агранат Б.А. и др. Основы физики и техники ультразвука // М.: Высшая школа. 1987. Vol. 352.

15. Kole M., Dey T.K. Thermophysical and pool boiling characteristics of ZnO-ethylene glycol nanofluids // International Journal of Thermal Sciences. 2012. Vol. 62. P. 61-70. doi: 10.1016/J.IJTHERMALSCI.2012.02.002.

16. Lee J.-H. et al. Effective viscosities and thermal conductivities of aqueous nanofluids containing low volume concentrations of $\mathrm{Al} 2 \mathrm{O} 3$ nanoparticles // International Journal of Heat and Mass Transfer. 2008. Vol. 51. No 11-12. P. 2651-2656. doi: 10.1016/J.IJHEATMASSTRANSFER.2007.10.026.

17. He Y. et al. Heat transfer and flow behaviour of aqueous suspensions of $\mathrm{TiO} 2$ nanoparticles (nanofluids) flowing upward through a vertical pipe // International Journal of Heat and Mass Transfer. 2007. Vol. 50. No 1112. P. 2272-2281. doi: 10.1016/j.ijheatmasstransfer. 2006.10.024.

18. Suganthi K.S., Rajan K.S. International Journal of Heat and Mass Transfer A formulation strategy for preparation of $\mathrm{ZnO}$ - Propylene glycol - water nanofluids with improved transport properties // International Journal of Heat and Mass Transfer. 2014. Vol. 71. P. 653-663. doi: 10.1016/j.ijheatmasstransfer.2013.12.044.

19. Yang J.-C. et al. Experimental investigation on the thermal conductivity and shear viscosity of viscoelasticfluid-based nanofluids // International Journal of Heat and Mass Transfer. 2012. Vol. 55. No 11-12. P. 3160-3166. doi: 10.1016/J.IJHEATMASSTRANSFER.2012.02.052.

20. Choi C., Yoo H.S., Oh J.M. Preparation and heat 
transfer properties of nanoparticle-in-transformer oil dispersions as advanced energy-efficient coolants // Current Applied Physics. 2008. Vol. 8. No 6. P. 710-712. doi: 10.1016/J.CAP.2007.04.060.

21. Кленин В.И., Щеголев С.Ю., Лаврушин В.И. Характеристические функции светорассеяния дисперсных систем. : Саратовского ун-та, 1977. 177 с.

22. Kourti T. Turbidimetry in Particle Size Analysis. , 2000. // Encyclopedia of Analytical Chemistry. 55495579. p.

23. Фролов Ю.Г. и др. Лабораторные работы и задачи по коллоидной химии. Химия, 1986. - 216 с.

24. Trisaksri V., Wongwises S. Nucleate pool boiling heat transfer of TiO2-R141b nanofluids // International Journal of Heat and Mass Transfer. 2009. Vol. 52. No 5-6. P. 1582-1588. doi: 10.1016/j.ijheatmasstransfer.2008.07.041. 25. Peng H., Ding G., Hu H. Effect of surfactant additives on nucleate pool boiling heat transfer of refrigerant-based nanofluid // Experimental Thermal and Fluid Science. 2011. Vol. 35. No 6. P. 960-970. doi: 10.1016/j.expthermflu sci.2011.01.016.

\title{
Study of the preparation technology of the working fluids with adding the nanoparticles $\mathrm{TiO}_{2}$ for the vapor compression refrigeration systems
}

\author{
O. Ya. Khlieva, T.V. Lukianova, Yu. V. Semenyuk, V.P. Zhelezny, S.G. Kornievich, O.Yu. Melnik \\ Odessa National Academy of Food Technologies, 112 Kanatna str., Odesa, 65039, Ukraine
}

\begin{abstract}
The interest to study of the prospects of the nanoparticles introduction into the working fluids of vapor compression refrigeration systems has been recorded in the scientific literature recent years. But the technologies of preparation the colloidally stable nanorefrigerants has not yet been developed. The approaches to the preparation of the working fluids consisting of halocarbons refrigerants and the metal oxides nanoparticles (nanorefrigerants) for the vapor compression refrigeration systems have been discussed in the paper. As the object of study for testing various technologies of the nanorefrigerant preparation the refrigerant $\mathrm{R} 141 \mathrm{~b}$ has been chosen. As additives to the nanorefrigerants the TiO $\mathrm{O}_{2} \mathrm{na}$ noparticles of two manufacturers and four surfactants of different nature have been chosen. The average size of nanoparticles in a liquid, determined by spectrotubidimetry method, has been taken as a criterion determining the quality of the obtained nanorefrigerant. It was concluded that combining the mechanical and ultrasonic methods of dispersion of nanoparticles in base fluids at the preparation of the nanorefrigerants by the two-step method is expedient. The results of the experimental study of the influence of the applied methods of the nanoparticles disperse and their duration, as well as the influence of the adding of different type of surfactants in various concentrations on the average size of nanoparticles in the obtained nanorefrigerants, are presented in the paper. It was chosen a surfactant (non-ionic surfactant Span 80) provided the preparation of colloidal stable nanofluids based on refrigerant $\mathrm{R} 141 \mathrm{~b}$ and $\mathrm{TiO}_{2}$ nanoparticles. It was shown that the procedure for determining the optimal concentration of surfactants for the preparation of nanorefrigerants is complex and this concentration depends on many factors. Probably with a decrease in the size of nanoparticles in a nanofluid (as a result of ultrasonic treatment), the required amount of surfactants increases to ensure the stability of nanoparticles (due to an increase in their specific surface area). Therefore, for each sample of nanorefrigerant the experimental determining the optimal concentration of surfactant is necessary before the study of the thermophysical properties or heat transfer processes.
\end{abstract}

Keywords: Refrigerant; Nanofluids; Surfactant; Colloidal stability; Nanoparticles size in nanofluid

\section{References}

1. Celen, A., Çebi, A., Aktas, M., Mahian, O., Dalkilic, A. S., \& Wongwises, S. (2014). A review of nanorefrigerants: Flow characteristics and applications. International Journal of Refrigeration, 44, 125-140. https://doi.org/10. 1016/j.ijrefrig.2014.05.009

2. Azmi, W. H., Sharif, M. Z., Yusof, T. M., Mamat, R., \& Redhwan, A. A. M. (2017). Potential of nanorefrigerant and nanolubricant on energy saving in refrigeration system - A review. Renewable and Sustainable Energy Reviews, 69, 415-428. https://doi.org/10.1016/j.rser.2016.11.207

3. Alawi, O. A., Sidik, N. A. C., \& Mohammed, H. A. (2014). A comprehensive review of fundamentals, preparation and applications of nanorefrigerants. International Communications in Heat and Mass Transfer, 54, 81-95. https://doi.org/10.1016/j.icheatmasstransfer.20
14.03.001

4. Lukianov M, Khliyeva O, Zhelezny V, Semenyuk Yu. (2015). Nanorefrigerants application possibilities study to increase the equipment ecological-energy efficiency. Eastern-European Journal of Enterprise Technologies, 3(5(75)), 32. https://doi.org/10.15587/1729-4061.2015. 42565

5. Moroz, S. A., Khlieva, O. Ya., Lukianov, N. N., Zheleznyi, V. P. (2016). Eksperimentalnoie issledovanie vlianiia primesei fullerenov C60 v kompressornom masle y velychiny viazkosti masla na pokazateli effektivnosti kholodilnoi kompressornoi sistemy. Vestnik Mezhdunarodnoi Akademii Kholoda, (1). 41-46 https://doi.org/10.21047/ 1606-4313-2016-16-1-41-46

6. Haddad, Z., Abid, C., Oztop, H. F., \& Mataoui, A. (2014). A review on how the researchers prepare their nanofluids. International Journal of Thermal Sciences, 76, 
168-189. https://doi.org/10.1016/j.ijthermalsci.2013.08.010 7. Devendiran, D. K., \& Amirtham, V. A. (2016). A review on preparation, characterization, properties and applications of nanofluids. Renewable and Sustainable Energy Reviews, 60, 21-40. https://doi.org/10.1016/ j.rser.2016.01.055

8. Ghadimi, A., Saidur, R., \& Metselaar, H. S. C. (2011). A review of nanofluid stability properties and characterization in stationary conditions. International Journal of Heat and Mass Transfer, 54(17-18), 4051-4068. https://doi.org/10.1016/j.ijheatmasstransfer.2011.04.014

9. Wu, D., Zhu, H., Wang, L., \& Liu, L. (2009). Critical Issues in Nanofluids Preparation, Characterization and Thermal Conductivity. Current Nanoscience, 5(1), 103112. https://doi.org/10.2174/157341309787314548

10. Yu, W., \& Xie, H. (2012). A Review on Nanofluids: Preparation, Stability Mechanisms, and Applications. Journal of Nanomaterials, 2012, 1-17. https://doi.org/10.1155/2012/435873

11. Diao, Y. H., Li, C. Z., Zhao, Y. H., Liu, Y., \& Wang, S. (2015). Experimental investigation on the pool boiling characteristics and critical heat flux of $\mathrm{Cu}-\mathrm{R} 141 \mathrm{~b}$ nanorefrigerant under atmospheric pressure. International Journal of Heat and Mass Transfer, 89, 110-115. https://doi.org/10.1016/j.ijheatmasstransfer.2015.05.043

12. Li, Y., Zhou, J., Tung, S., Schneider, E., \& Xi, S. (2009). A review on development of nanofluid preparation and characterization. Powder Technology, 196(2), 89-101. https://doi.org/10.1016/J.POWTEC.2009.07.025

13. Peng, H., Lin, L., \& Ding, G. (2015b). Influences of primary particle parameters and surfactant on aggregation behavior of nanoparticles in nanorefrigerant. Energy, 89, 410-420. https://doi.org/10.1016/j.energy.2015.05.116 14. Ahranat, B. A., Dubrovin, M. N., Khavskyi, N. N., Eskyn, H. Y. (1987). Osnovy fiziki i tekhniki ultrazvuka. M.: Vysshaia Shkola, 352.

15. Kole, M., \& Dey, T. K. (2012). Thermophysical and pool boiling characteristics of ZnO-ethylene glycol nanofluids. International Journal of Thermal Sciences, 62, 61-70. https://doi.org/10.1016/j.ijthermalsci.2012.02.002

16. Lee, J.-H., Hwang, K. S., Jang, S. P., Lee, B. H., Kim, J. H., Choi, S. U. S., \& Choi, C. J. (2008). Effective viscosities and thermal conductivities of aqueous nanofluids containing low volume concentrations of $\mathrm{Al} 2 \mathrm{O} 3$ nanoparticles. International Journal of Heat and Mass Transfer, 51(11-12), 2651-2656. https://doi.org/10.1016/ j.ijheat masstran sfer. 2007.10.026

17. He, Y., Jin, Y., Chen, H., Ding, Y., Cang, D., \& Lu, H. (2007). Heat transfer and flow behaviour of aqueous suspensions of $\mathrm{TiO} 2$ nanoparticles (nanofluids) flowing upward through a vertical pipe. international journal of heat and mass transfer, 50(11-12), 2272-2281. https://doi.org/10.1016/j.ijheatmasstransfer.2006.10.024

18. Suganthi, K. S., \& Rajan, K. S. (2014). International Journal of Heat and Mass Transfer A formulation strategy for preparation of $\mathrm{ZnO}$ - Propylene glycol - water nanofluids with improved transport properties. International Journal of Heat and Mass Transfer, 71, 653-663. https://doi.org/10.1016/j.ijheatmasstransfer.2013.12.044

19. Yang, J.-C., Li, F.-C., Zhou, W.-W., He, Y.-R., \& Jiang, B.-C. (2012). Experimental investigation on the thermal conductivity and shear viscosity of viscoelasticfluid-based nanofluids. International Journal of Heat and Mass Vol. 55, Issue 11. - P. 3160-3166.

20. Choi, C., Yoo, H. S., \& Oh, J. M. (2008). Preparation and heat transfer properties of nanoparticle-in-transformer oil dispersions as advanced energy-efficient coolants. Current Applied Physics, 8(6), 710-712. https://doi.org/10.1016/J.CAP.2007.04.060

21. Klenyn, V. Y., Shcheholev, S. Yu., Lavrushyn, V. Y. (1977). Kharakteristicheskie funktsii svetorasseianiia dyspersnykh sistem. Saratovskoho un-ta, 177.

22. Kourti, T. (2000). Turbidimetry in Particle Size Analysis. Encyclopedia of Analytical Chemistry, 55495579. https://doi.org/10.1002/9780470027318.a1517

23. Frolov, Yu. H., Hrodskyi, A. S., Nazarov, V. V., \& Morhunov, A. F. (1986). Laboratornыe rabotы y zadachy po kolloydnoi khymyy. Khymyia, 6.

24. Trisaksri, V., \& Wongwises, S. (2009). Nucleate pool boiling heat transfer of $\mathrm{TiO} 2-\mathrm{R} 141 \mathrm{~b}$ nanofluids. International Journal of Heat and Mass Transfer, 52(5-6), 1582-1588. https://doi.org/10.1016/j.ijheatmasstransfer.20 08.07 .

25. Peng, H., Ding, G., \& Hu, H. (2011). Effect of surfactant additives on nucleate pool boiling heat transfer of refrigerant-based nanofluid. Experimental Thermal and Fluid Science, 35(6), 960-970. https://doi.org/10.1016/j.exp ther mflusci. 2011.01.016 